\title{
The tectonic uplift since the Late Cretaceous and its impact on the preservation of hydrocarbon in southeastern Sichuan Basin, China
}

\author{
Huaiqing Liu ${ }^{1,2} \cdot$ Yong Tang ${ }^{1,3} \cdot$ Kongquan Chen ${ }^{1} \cdot$ Wenjun Tang ${ }^{4}$
}

Received: 8 October 2016/Accepted: 27 November 2016/Published online: 10 December 2016

(C) The Author(s) 2017. This article is published with open access at Springerlink.com

\begin{abstract}
Tectonic uplift is the most direct manifestation of tectonic activity, and tectonic deformation strength can be quantitatively shown through uplift height and speed. In this study, balanced rebound and oxygen isotope method are adopted to calculate maximum paleoelevation of stratum uplift of southeastern area of Sichuan Basin since Late Cretaceous due to tectonic activities. And based on current surface elevation of the target area, stratum erosion thickness of southeastern Sichuan during this period is calculated, thereby providing technical support for evaluation of the regional oil and gas exploration. Studies have shown that maximum paleoelevation of southeastern Sichuan uplift is gradually increased from NW to SE, which can
\end{abstract}

The original version of this article was revised: Some of the affiliations were incorrectly indicated. Also the sequence has been changed. Moreover, throughout the article "Qiyueshan" has been corrected to "Qiyushang".

Yong Tang

water_0820@163.com

Huaiqing Liu

499671886@qq.com

Kongquan Chen

30760410@qq.com

Wenjun Tang

386824442@qq.com

1 Hubei Cooperative Innovation Center of Unconventional Oil and Gas, Yangtze University, Wuhan 430100, China

2 Wuhan Center of Geological Survey, CGS, Wuhan 430205, Hubei, China

3 Key Laboratory of Tectonics \& Petroleum Resource of the Ministry of Education, China University of Geosciences, Wuhan 430074, China

4 Cainan Operation District of Xinjiang Oilfield Company CNPC, Fukang 831511, China maximally achieve $3813 \mathrm{~m}$. Denudation quantity from Sichuan Basin to Qiyushang is gradually increased, and region with greater erosion thickness is above $2800 \mathrm{~m}$. Since the Late Cretaceous, southeastern Sichuan stratum uplift makes oil and gas in Dingshan block gradually dissipate. Also, overlying rock unloading results in fault development, early fault activation, and expansion, which further exacerbates destroy of oil and gas reservoir in Dingshan block of southeastern Sichuan, China.

Keywords Tectonic uplift · Paleoelevation - Erosion · Southeastern Sichuan Basin · Oil and gas

\section{Introduction}

Construction and denudation, which mutually influence mountains and basins, are classic research topics in earth science. The current study suggests two aspects: On the one hand, the construction is achieved by shortening in the horizontal direction, which leads to thicker rock, crust floating, and Earth's surface uplift (Green. 1986; Metiver and Gaudenmer 1997; Yuan et al. 2011; Zhao et al. 2013); on the other hand, erosion causes the release of the overlying load, which then leads to isostatic rebound and an uplifting point elevation above the peripheral edge of the area and thus to a great difference in the ancient topography and landscape (Willett and Brandon 2002; Garzione et al. 2004; Stern et al. 2005; Munt et al. 2010). In fact, isostatic rebound and erosion adjust the material balance. In other words, the denudation will cause readjustment of the entire material balance, stress field, and overburden pressure equalization (Ye et al. 2000; Huang et al. 2012). The oil and natural gas occurrence in the sedimentary layer and enrichment region will change accordingly during the adjustment process. 
Research on the recovery of the denudation quantity and the quantitative recovery of paleoaltimetry plays an important role in guiding the adjustment analysis of oil-gas migration and the evaluation of storage conditions.

\section{Geological setting}

The Sichuan Basin and the periphery have undergone several tectonic activities since the Late Cretaceous, causing the uplift and denudation of sedimentary rocks. As a result, the sediment thickness and terrain elevation of each stage differ greatly from the current remaining thickness and elevation (Fu et al. 2008). The uplift and denudation cause changes in underground energy fields, especially the temperature and pressure fields, resulting in oil and gas remigration and readjustment, which are important for the control of the current distribution of oil and gas reservoirs. Rebuilding the elevation evolution history and the uplift of the terrain unit will promote the understanding of oil-gas migration and accumulation. The accurate portraying of the paleoaltimetry evolution of southeastern Sichuan since the Late Cretaceous using quantitative methods provides a strong reference for the oil and gas exploration and development in southeastern Sichuan. The paleoaltimetry of southeastern Sichuan will be restored with oxygen isotope and isostatic rebound methods, the denudation quantity of southeastern Sichuan will be calculated, and the impact of the denudation quantity on the oil and gas reservoir transformation of the Dingshan block in southeastern Sichuan will be discussed.

The depression fold belt of southeastern Sichuan is located in the high steep structure belt of eastern Sichuan and the even lower structure belt of southern Sichuan of the Sichuan Basin, which develops a series of high steep anticline structures in the north-northeast direction. The southeastern margin of the Sichuan Basin is located in the transfer and conversion parts of the Tethys-Himalayan tectonic domain and the marginal-pacific tectonic domain, with late Cenozoic tectonic movement characteristics such as the north-south Nanchuan-Zunyi structure, northeast mulberry field structure, main east-west Chishui structure, and northwest Changning-Shuanghe structure (Wang et al. 2011). The Dingshan structure of southeastern Sichuan is located in the transition region of the low steep fold belt and the trough-like fold in the basin margin transition region, close to the Qiyushang fracture of the eastern border of the Sichuan Basin, with surface exposure of Triassic-Ordovician and more developed fractures. The entire southeastern Sichuan Caledonian is located at the Leshan-Longnvsi paleohigh southeastern ramp; Indosinian is located at the southeastern slope of the Luzhou paleouplift (Zhai 2013); and the Yanshan-Himalayan is a critical period of the formation and tectonic setting of the southeastern structure.
After the Yanshan-Himalayan structure transformation, the anticline core of the southeastern Sichuan Basin (southern Sichuan low steep fold belt) generally appears in the lower Triassic, and the syncline core occurs in the middle and upper Jurassic Shaximiao and Penglaizhen formations, while the anticline core of the edge of the Sichuan Basin of the southeastern region (Sichuan, Guizhou hedge transition zone) generally occurs in the Ordovician, and the syncline core appears in the lower Triassic-Silurian (Fig. 1).

\section{Method}

\section{Equilibrium model recovery method}

To study the lithosphere flexural strength, the theory response and cross-correlation functions are calculated based on the lithosphere model of the sheet flexure, the response function and cross correlation functions are explained in the actual calculation, and the flexural strength of the lithosphere is then determined. The lithosphere model of the sheet flexure considers the flexural deflection of the elastic sheet (corresponding to lithosphere) on nonviscous, incompressible fluid (corresponding to asthenosphere) with topographic load. The so-called sheet refers to the vertical displacement with a flexural wavelength much larger than the plate thickness and deflection. The flexing stress of the spherical shell of the spherical Earth consists of bending stress and film stress. It is reasonable to study the lithosphere using a plane elastic sheet model when the wavelength of the load is smaller than the Earth's radius and larger than the plate thickness (Daniel and Juan 2015).

The method proposes a period of the simple basin of beginning development of maximum sedimentary fill, but it requires the following conditions: (1) a determined time and a stratigraphic basin section with sufficient thickness are required; (2) the volume of overall sediment erosion from the basin needs to be limited; and (3) for equal deflection of the rock thickness in the area, the set of data is obtained from previous studies. The method mainly reflects the denudation quantity by restoring the vertical basin uplift and searching the maximum value of the paleoelevation of the regional filling using an isostatic warping flexural model. The denudation quantity is primarily determined by single well restoration (Champagnac et al. 2007; Gudmundsson 1994). The deposition rate of the stratigraphic section is then obtained, and the latest age of the sediment accumulation with the maximum value of paleoelevation (before denudation) is determined (Fig. 2).

Taking into account current geomorphic features formed by denudation in the study area, the cumulative geomorphic difference can be calculated from the denudation quantity at the start of the maximal deposition when the 


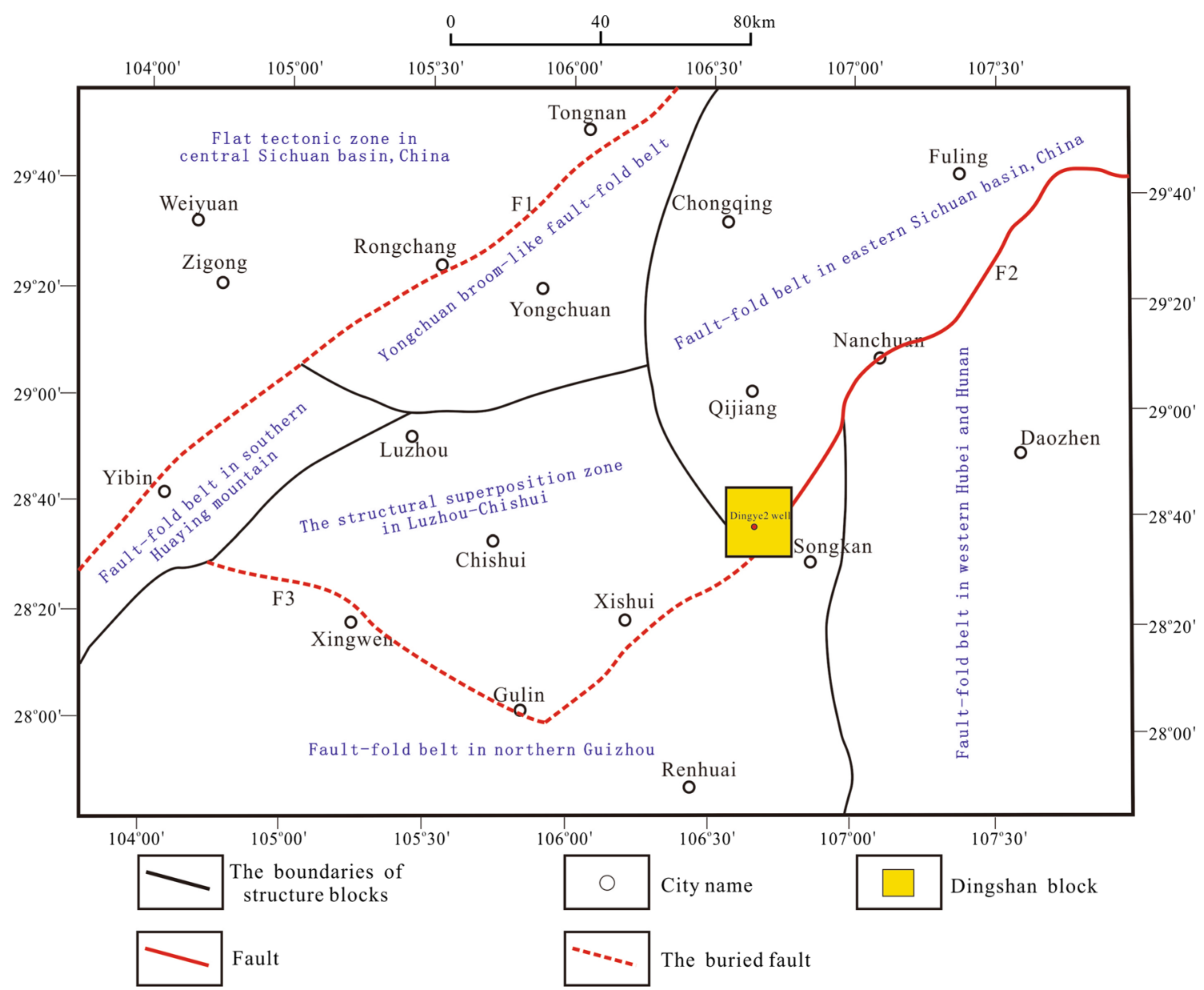

F1:Huayingshan fault

F2:Qiyueshan fault

F3:Xingwen-Gulin fault

Fig. 1 Location of Dishan block in southeastern Sichuan Basin, China
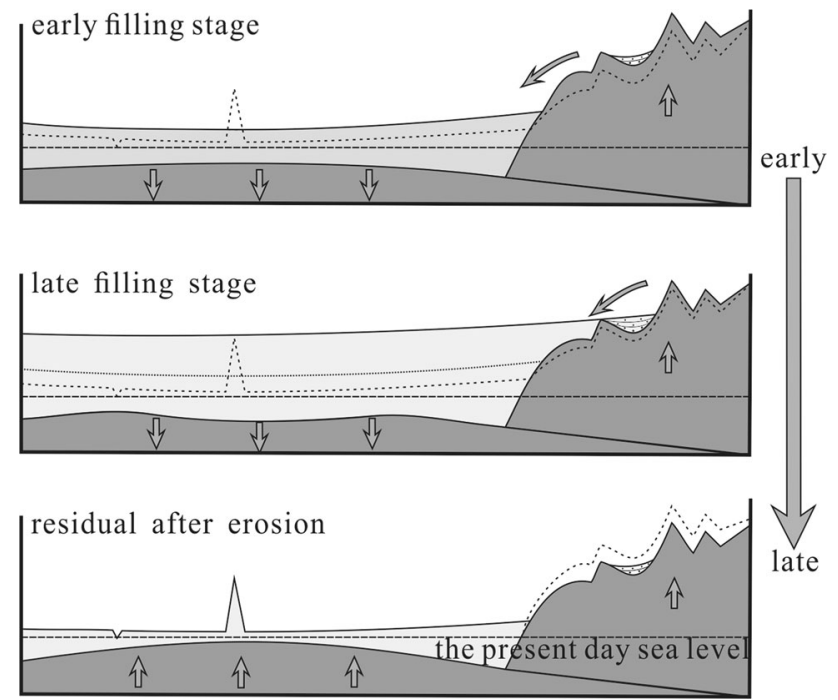

Fig. 2 The schematic diagram of filling, erosion, and the elasticity recovery. (Modified from Daniel and Juan 2015) basin reaches the maximum sediment filling surface. The cumulative geomorphic difference is the difference between the maximum altitude $Z_{\max }$ and the current altitude, which is the actual denudation quantity of the study area after coupling with rebound $w$, representing the vertical direction of the crust. The sediment denudation $V_{\mathrm{e}}$ can be formulated as (Daniel and Juan 2015):

$V_{e}=\iint\left[z_{\max }(x, y)-z_{t}(x, y)+w(x, y)\right] \mathrm{d} x \mathrm{~d} y$

where $V_{\mathrm{e}}$ is the sediment denudation. $w(x, y)$ refers to the crust-compensatory rebound after sediment denudation and the weight loss of the overlying part of the sediment, which can be calculated using the thin-plate approach.

$\nabla^{2}\left(D \nabla^{2} w\right)+\left(\rho_{\mathrm{a}}-\rho_{\mathrm{s}}\right) g w=\rho_{\mathrm{s}} g\left[z_{\max }(x, y)-z_{t}(x, y)\right]$

$D \frac{\mathrm{d}^{4} w(x)}{\mathrm{d} x^{4}}+\left(\rho_{\mathrm{a}}-\rho_{\mathrm{s}}\right) g w(x)=q(x)-\bar{q}$ 
$D=\frac{E T_{\mathrm{e}}^{3}}{12\left(1-v^{2}\right)}$

where $\rho_{\mathrm{a}}$ and $\rho_{\mathrm{s}}$ are the density of the sediment and asthenosphere, respectively, $T_{\mathrm{e}}$ is the equivalent elastic thickness, $D$ is the elastic stiffness and equivalent elastic thickness, $v$ is the Poisson's ratio, and $E$ is the Young's modulus.

From the selection of a point $X_{\mathrm{d}}, Y_{\mathrm{d}}, Z_{\mathrm{d}}$ on the basin ground of the current study area, the deposition time $t_{\mathrm{d}}$ at the position and the old-time deposition rate $R_{\mathrm{d}}$ can be obtained. The selected point of the rock profile is $z_{\mathrm{d}}-$ $w\left(x_{\mathrm{d}}, y_{\mathrm{d}}\right)$ at $t_{\max }$ elevation. Thus, $t_{\max }$ can be calculated using the following formula.

$t_{\max }=t_{\mathrm{d}}+\left[z_{\max }-z_{\mathrm{d}}+w\left(x_{\mathrm{d}}, y_{\mathrm{d}}\right)\right] / R_{\mathrm{d}}$

where $t_{\mathrm{d}}$ is negative, $t_{\mathrm{d}}=0$ represents the current, $W>0$ indicates uplift, and $Z_{\max }$ is unknown. If the equivalent elastic thickness $T_{\mathrm{e}}$ is determined, we can calculate $z_{\max }$ from the denudation quantity and $t_{\max }$. In the current simulation, the crustal equivalent thickness of southeastern Sichuan, $T_{\mathrm{e}}$, is $30 \pm 5 \mathrm{~km}$.

The above-mentioned elastic sheet model calculations are based on the assumption that all loads of the elastic deformation are characterized by Earth's response to load, which is stable in space. Various non-uniform loads within the continental lithosphere caused by magmatic intrusion, metamorphism, and phase change are excluded from this calculation process for southeastern Sichuan.

\section{Paleoelevation calculation using oxygen isotopes}

The lapse rate of the oxygen isotope content in rainfall with elevation increase in the study area is calculated based on the relationship between oxygen isotope data of modern precipitation and altitude to estimate the paleoelevation from oxygen isotopes of authigenic minerals. Moisture condenses when air mass lifts along the high terrain, which can cause the kinetic fractionation of oxygen isotopes. The higher the elevation is, the lower is the ${ }^{18} \mathrm{O}$ content in precipitation. This fractionation conforms to the Rayleigh fractionation law (Yang and Wang 2007). If mountain rivers and lakes of geological time mainly rely on the replenishment of local precipitation, the lakes and rivers will be able to record the change in the oxygen isotope content in precipitation with elevation. Authigenic minerals in rivers and lakes often achieve a balance with the atmospheric water in oxygen isotopes during precipitation, which can be used to study the paleoelevation change in the stratum (Liu et al. 2009).

A large number of scholars have established the relationship between the isotopic decline rate and elevation. (Garzione et al. 2000) and Rowley et al.(2001)obtained the empirical formula of the isotopic composition change and elevation based on Himalayas deposition and elevation data and estimated the Miocene-Pliocene elevation range of the southern Qinghai-Tibet Plateau (Jiang et al. 2015).

$\delta^{18} O_{h}=-(2.6 E-7) h^{2}-0.0013 h-\delta^{18} O_{s l}$

where $\mathrm{h}$ is the elevation above sea level and $\delta^{18} \mathrm{O}_{\mathrm{sl}}$ is the isotopic composition of atmospheric water. The isotopic composition matches the corresponding sea level. Currently, the main method of oxygen isotope paleoelevation recovery is more often used in the Qinghai-Tibet Plateau. Study carriers are lake carbonate rock, soil carbonate rock, and biological fossils containing phosphate or carbonate that are formed by river/lake precipitation in geological history. The $\delta^{18} \mathrm{O}$ value in carbonate is converted to $\delta^{18} \mathrm{O}$ of ancient lakes or rivers.

The most important prerequisite for the usage of the oxygen isotope paleoaltimeter is to ensure that the $\delta^{18} \mathrm{O}$ value of the used sample can reflect the $\delta^{18} \mathrm{O}$ value in original precipitation. The $\delta^{18} \mathrm{O}$ value is mainly affected by two factors: late diagenesis and evaporation (Talbot 1990). Once recrystallization occurs in carbonate rock during diagenesis, the $\delta^{18} \mathrm{O}$ value will be somewhat disturbed; evaporation causes the increase in the lake water salinity, leading to an increased $\delta^{18} \mathrm{O}$ value used to estimate the paleoelevation. The error can be modified by precise data points (logging recovery).

\section{Results}

Southeastern Sichuan has been in the uplift deformation phase since the Late Cretaceous due to southeast and northwest extrusions of the Jiangnan uplift. The EoceneOligocene rapid uplift is especially important because it caused a new paleoelevation high in the study area (Li et al. 2009; Wang et al. 2012; Mei et al. 2010). The quantitative analysis of the paleoelevation is of great value for the evaluation of the denudation quantity restoration in the study area and the preservation conditions of shale gas in Longmaxi of the region.

\section{Paleoelevation estimation with partial isostatic compensation}

Based on apatite fission track analysis, Deng (2013)reported that the general denudation increase in the southeastern Sichuan Basin since the Late Cretaceous reaches $2000 \mathrm{~m}$ and that of the eastern region of Qiyushang in southeastern Sichuan is relatively high, generally greater than $3200 \mathrm{~m}$. The study is based on interval transit time calculation and analysis of the Ximen 1, Dingye 2, and Ling 1 wells of Southwest Oil \& Gas Field Company. The 


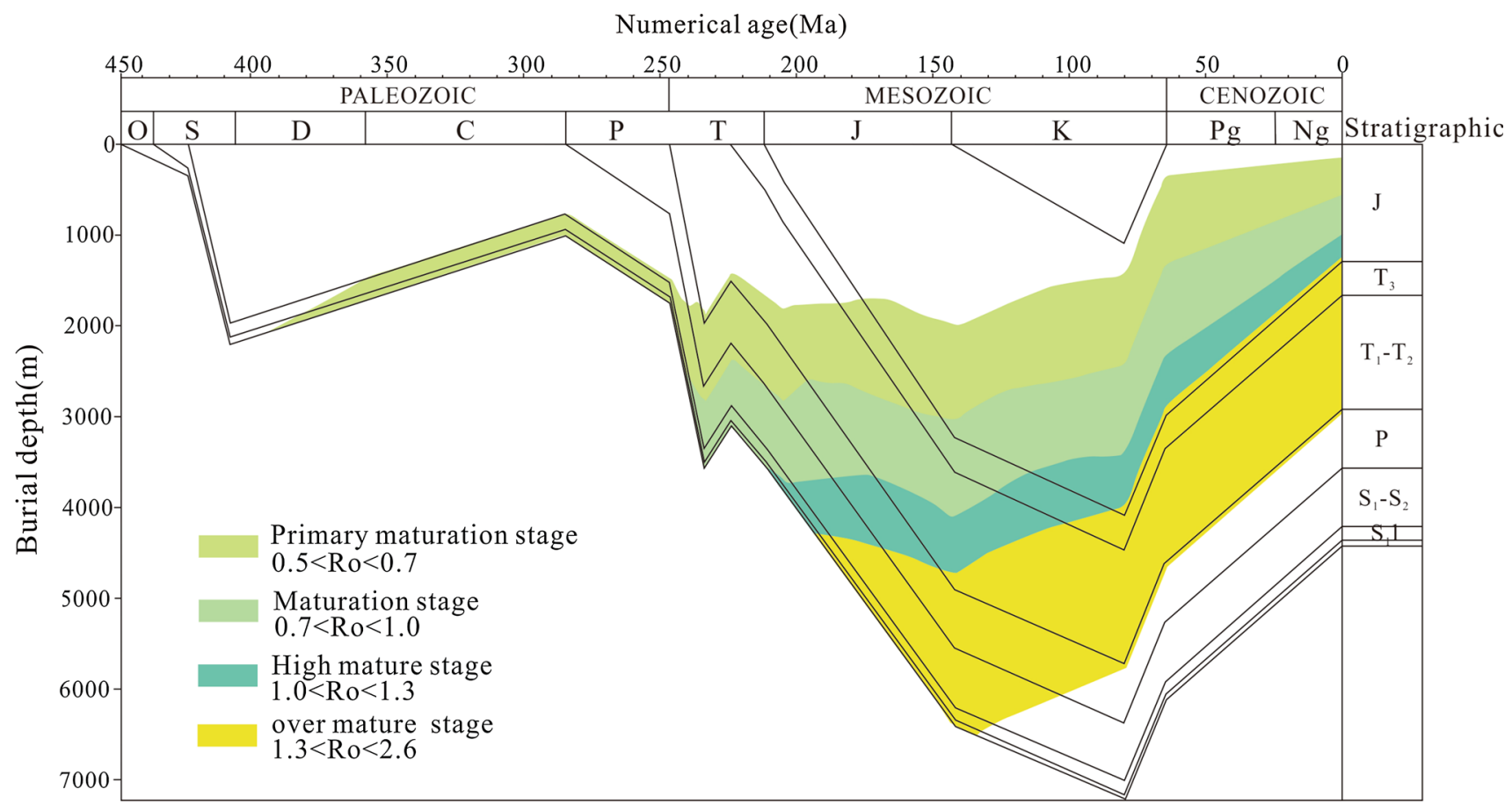

Fig. 3 The burial history of Well Dingye 2

denudation quantity of the 3 wells reached 1115, 2811, and $2850 \mathrm{~m}$ (Figs. 3, 4), respectively, which indicates that the denudation thickness gradually increases from the inside to the outside of the basin. Both sides of the tectonic zone of Qiyushang show different sediment formations and tectonic deformation but have a similar deep lithosphere structure. The target strata thickness of southeastern Sichuan is 650-310 m, the deposition rate is $43.06-90.28 \mathrm{~m} / \mathrm{Ma}$, and the crustal equivalent thickness is $30 \pm 5 \mathrm{~km}$ (Wang et al. 1996; Deng 2013), according to the calculation of the equilibrium rebound using the Upper Triassic Xujiahe Formation as calculation object. Based on this calculation, the isostatic rebound of southeastern Sichuan is 23-1043 m, with the total amount of crustal rebound gradually increasing from the interior of the basin to the southeast. It reaches a peak with the equilibrium compensation volume above $1000 \mathrm{~m}$ in the Qiyushang fault zone. Away from the Qiyushang fault zone, the equilibrium rebound of the western Sichuan Basin is less than $500 \mathrm{~m}$.

\section{Estimation of maximum paleoelevation using oxygen isotopes}

The errors caused by mineral samples in paleoelevation projection will be great. Therefore, the mineral samples have to be carefully selected. Authigenic minerals in mountain sag deposition, such as calcite, kaolinite, and montmorillonite, can be used as samples for this approach. The estimation of oxygen isotopes in calcite is used to

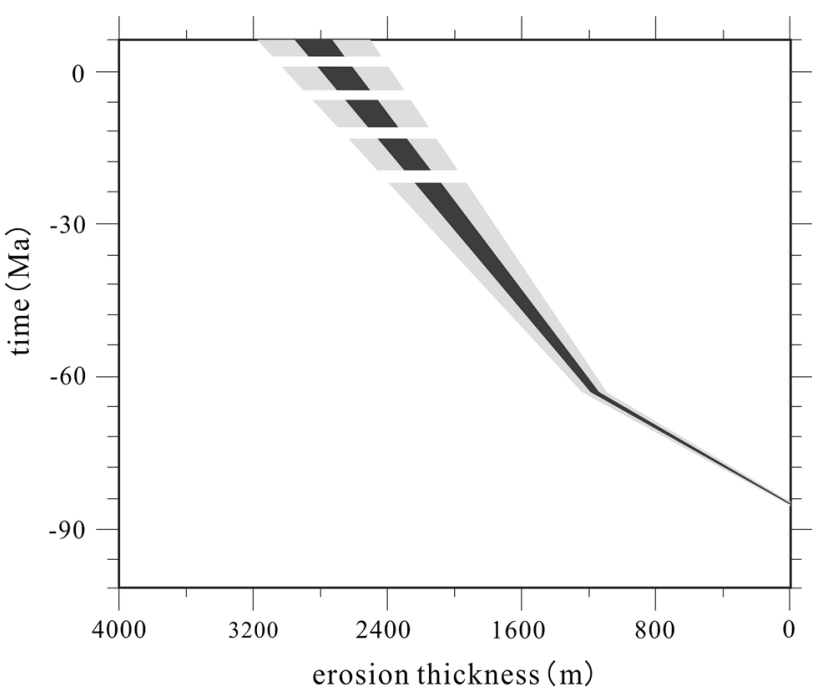

Fig. 4 Denudation thickness in southeastern Sichuan Basin

determine the paleoelevation of the region before denudation and to understand the evolutionary denudation history of southeastern Sichuan since the Late Yanshanian.

The key to obtain reliable paleoelevation data is to choose good carbonate rock samples and reasonable regression formulas. Previous studies have shown that the oxygen isotopes in lacustrine sediments, secondary carbonates in fluvial facies, and pedogenic carbonates can be used to study the paleoelevation (Garzione et al. 2000; Dettman and Lohmann 2000). Wu et al. (2007) found a good correlation between the statistical analysis of carbon

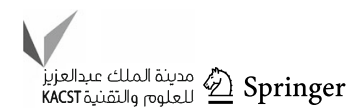




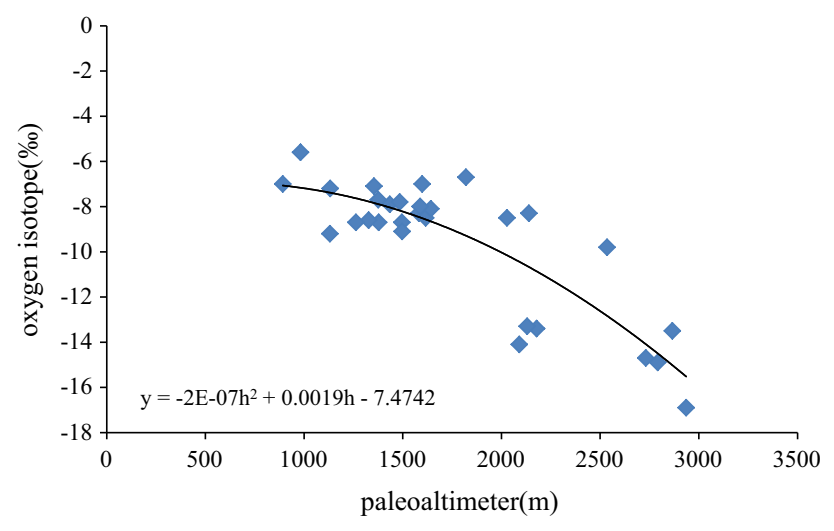

Fig. 5 The relation between oxygen isotope and paleoaltimeter in Sichuan Basin, China

and oxygen isotopes of quaternary lacustrine sediments of the southern Tibetan Plateau and the altitude of the sampling sites. The carbon and oxygen isotopes of lacustrine sediments and the paleoelevation in the developmental phase of lakes also correlate. Thus, the paleoelevation of the Late Cenozoic of Tibetan Plateau can be estimated. Several rivers and the surface water of the southeastern region of Sichuan were sampled in this study for oxygen isotope analysis, regression analysis of oxygen isotopes in modern surface water, and elevation data analysis (Fig. 5; Table 1). The results showed that the oxygen isotopes decrease with the increase in elevation. We have considered that oxygen isotope varies from $-5.6 \%$ at $982 \mathrm{~m}$ elevation to $-16.9 \%$ at $2936 \mathrm{~m}$ elevation. Therefore, we find that there exists better correlation between the elevation and the oxygen isotopes. There is no correlation relationship between the elevation and the carbon isotopes. The empirical relationship formula of paleoelevation and oxygen isotope changes depending on the terrain was then deduced. The empirical formula for the southeastern Sichuan oxygen isotope paleoaltimeter is:

$\delta^{18} O_{h}=-(2.0 E-7) h^{2}+0.0019 h-7.4742$

where $h$ is the elevation above sea level and $\delta^{18} \mathrm{O}_{h}$ is the isotopic composition in atmospheric water.

Samples collected in this study are from the Shangmuchang anticline of the southeastern Sichuan Basin and the southern region of the Sichuan Basin in the Northwest, mainly from Cretaceous outcrops, Jurassic sandstone calcite, and Triassic authigenic carbonate rock. Detailed analysis of $\mathrm{C}$ and $\mathrm{O}$ isotopes was performed for each sample. The oxygen isotopes are mainly in the range of -5.6 to $-16.9 \%$, the elevation of carbonate rock is $282-1436 \mathrm{~m}$, and the elevation of most samples is in the upper and lower ranges of $600 \mathrm{~m}$. To estimate the paleoelevation using oxygen isotopes, it should be confirmed that the $\delta^{18} \mathrm{O}$ values of the samples used reflect the $\delta^{18} \mathrm{O}$ values of the original precipitation. No notable difference of the carbon isotopes of carbonate rock
Table 1 Oxygen isotope and paleoaltimeter in Sichuan Basin, China

\begin{tabular}{|c|c|c|}
\hline Paleoaltimeter (m) & $\delta^{18} \mathrm{O}(\%)$ & $\delta^{13} \mathrm{C}(\%)$ \\
\hline 892 & -7 & -2.2 \\
\hline 1495 & -8.7 & -0.4 \\
\hline 2139 & -8.3 & -1.5 \\
\hline 2866 & -13.5 & 1.1 \\
\hline 2090 & -14.1 & 1.2 \\
\hline 2936 & -16.9 & 0.8 \\
\hline 2178 & -13.4 & -1.1 \\
\hline 1354 & -7.1 & -5 \\
\hline 982 & -5.6 & -4.8 \\
\hline 1378 & -8.7 & -1 \\
\hline 1327 & -8.6 & -1.7 \\
\hline 2130 & -13.3 & 1 \\
\hline 2731 & -14.7 & 1.5 \\
\hline 2792 & -14.9 & -1.2 \\
\hline 1434 & -7.9 & -1.3 \\
\hline 1820 & -6.7 & -2.9 \\
\hline 1484 & -7.8 & -2.7 \\
\hline 2535 & -9.8 & -1.6 \\
\hline 2028 & -8.5 & -0.2 \\
\hline 1497 & -9.1 & -2.2 \\
\hline 1582 & -8.3 & 0.7 \\
\hline 1616 & -8.5 & -2 \\
\hline 1642 & -8.1 & -3.3 \\
\hline 1598 & -7 & -0.5 \\
\hline 1588 & -8 & -1.1 \\
\hline 1263 & -8.7 & 0 \\
\hline 1131 & -9.2 & -1.2 \\
\hline 1376 & -7.7 & -0.8 \\
\hline 1132 & -7.2 & -1 \\
\hline
\end{tabular}

samples from slightly different locations and elevations was observed, which indicates that the diagenesis and evaporation affect the carbonate rock samples minimally. The micrograph of the microcrystalline carbonate rock of the eogenetic stage of carbonate shows an extremely small disturbance of the $\delta^{18} \mathrm{O}$ value in the diagenetic stage A. The maximum paleoelevation of southeastern Sichuan since the Late Cretaceous was calculated and analyzed based on field sampling data. Based on the regression, the largest paleoelevation of $3813 \mathrm{~m}$ is located approximately $5 \mathrm{~km}$ from the southeastern town of Songkan, while the lowest paleoelevation of approximately $437 \mathrm{~m}$ was measured approximately $3 \mathrm{~km}$ from the southeastern town of Rongchang. The paleoelevation gradually increases from northwest to southeast. The area of Bailu town-Wanglong town constitutes an inflection point, which shows a sharp rise in paleoelevation (Fig. 6). There is a slight difference in the estimated data of individual sampling points. For example, the estimated data of the Xindianzi anticline in southeastern Rongchang town 


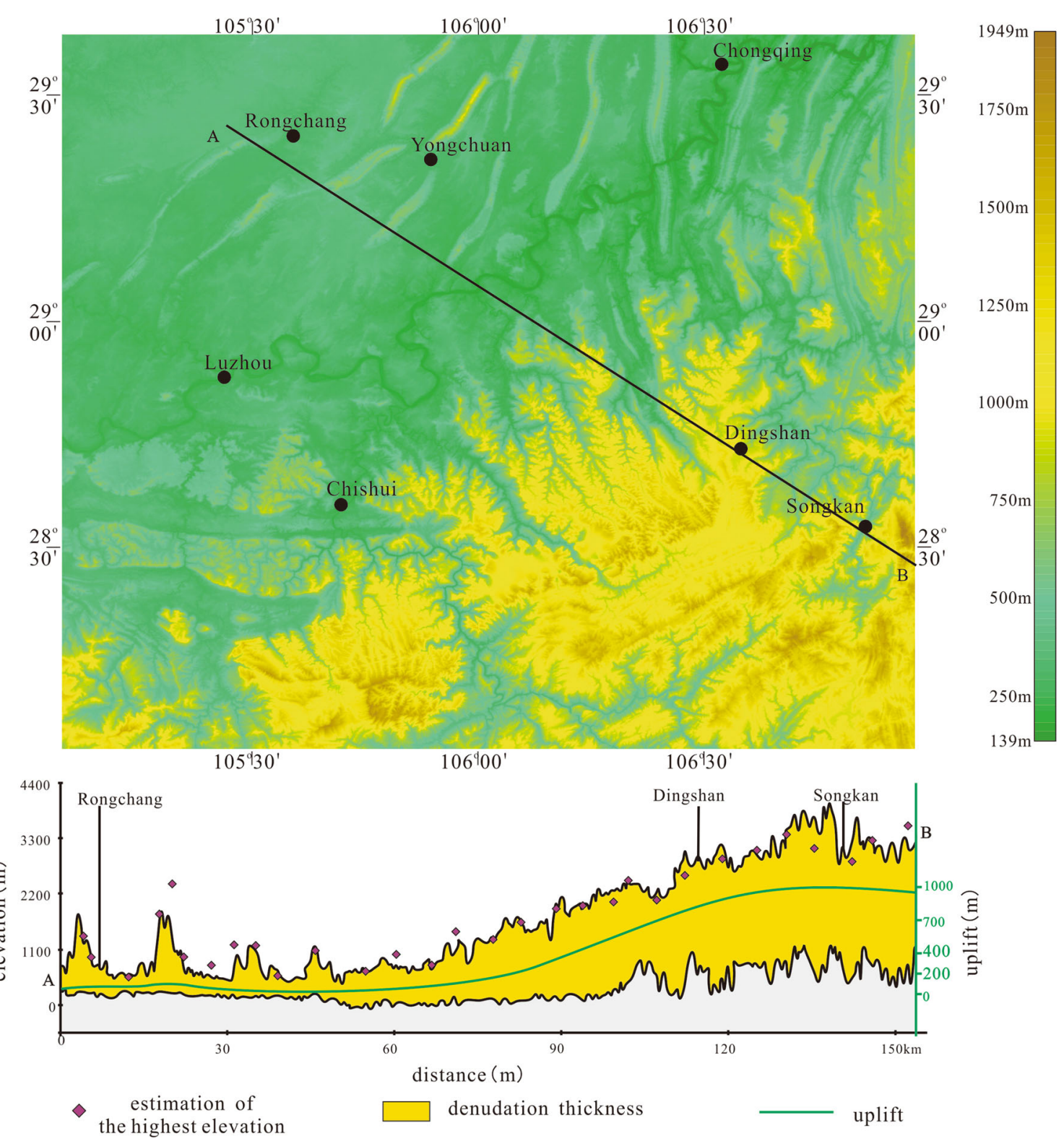

Fig. 6 The paleoaltimeter and the equilibrium rebound in southeastern Sichuan Basin, China

are relatively large, with some differences due to the tectonic uplift history of southeastern Sichuan. However, other results show relatively large credibility. Direct evidence was obtained from the denudation recovery of the Dingye 2 and Ling1 wells. The denudation thickness of Datong townSongkan town can reach $2811 \mathrm{~m}$.

\section{Discussion}

\section{Dynamic mechanism of uplift}

The distance from the Xuefeng Mountain uplift to the Sichuan Basin Huaying Mountain through the Hubei,
Hunan, and Guizhou borders is nearly $400 \mathrm{~km}$. The main body is composed of thrust-fold combinations. The tectonic zone is related to the formation and properties of the Xuefeng Mountains and the orogenes is of the Mesozoic and Cenozoic. Southeastern Sichuan has a tectonic shortening rate of $21.2-41.1 \%$ (Fig. 7). Apatite fission track thermal simulation reveals 2 rapid uplift processes in the southeastern Sichuan region: (1) one period at approximately $90-60 \mathrm{Ma}$ and (2) another period at $45-25 \mathrm{Ma}$ (Shen et al. 2009; Deng et al. 2014). The two phases of intense tectonic activities reflect fast uplift-cooling events in the Late Cretaceous and early Cenozoic ( $\mathrm{Li}$ et al. 2008; Shen et al. 2012; Ge et al. 2013). The intracontinental orogenic system of Xuefeng in the Late Cretaceous is still 


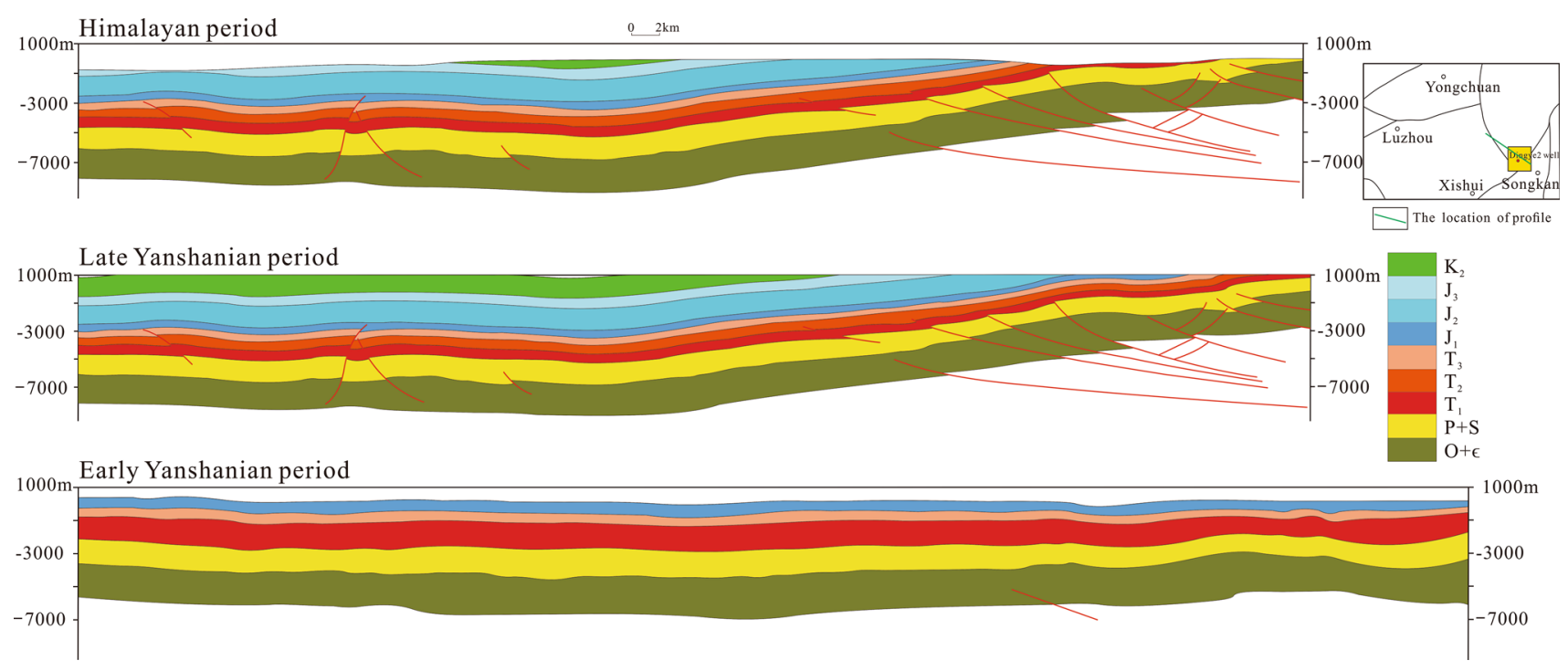

Fig. 7 The balanced structural section analysis of Dishan block and its surrounding area in southeastern Sichuan Basin, China

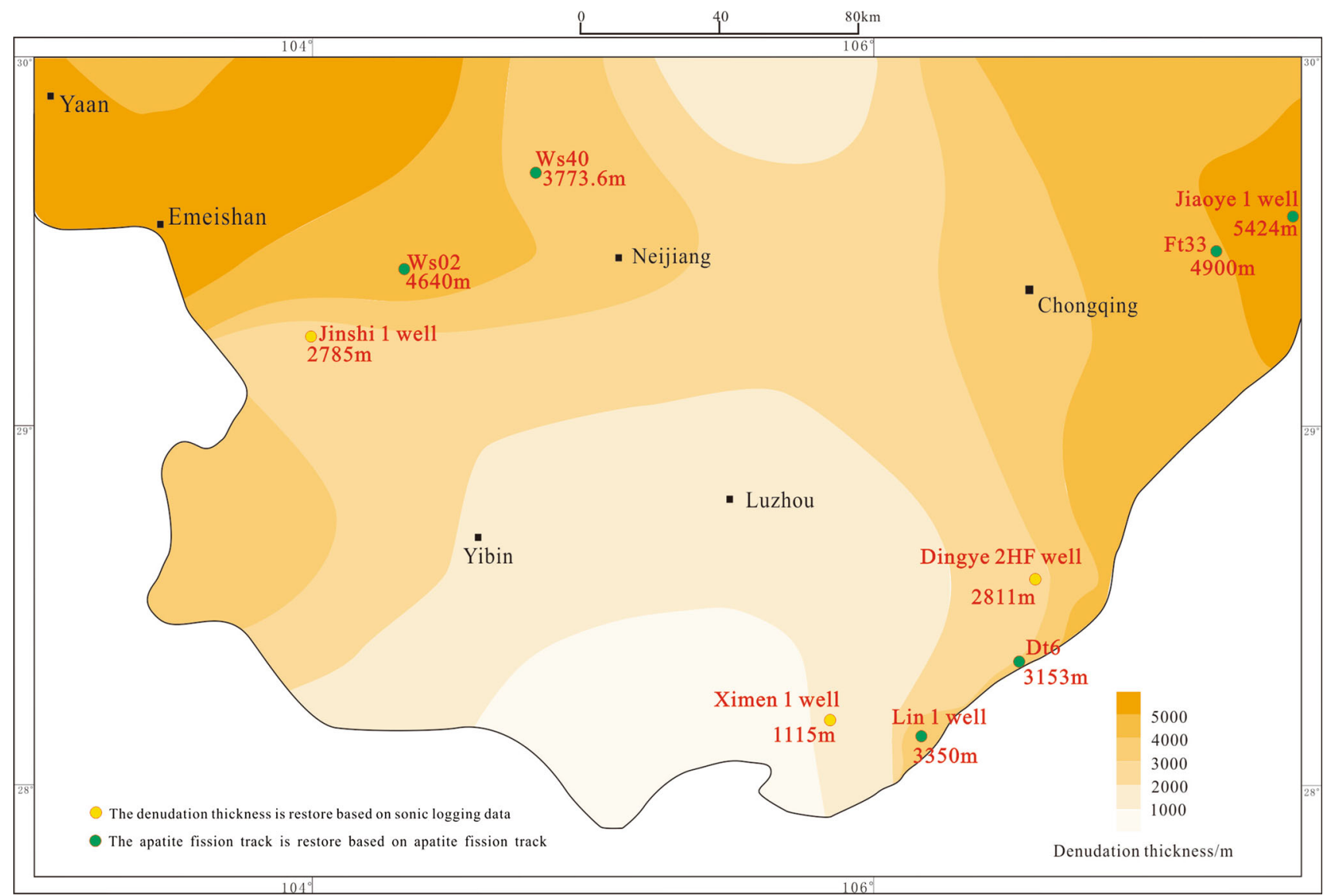

Fig. 8 The denudation thickness since the Late Cretaceous

under deformation with northwest extension. The subduction push of the South China plate by the Indian and the Pacific plates causes basal detachment and sliding surfaces, which results in the imbricated reciprocal push of the
Xuefeng Mountains to the west. Under such a strong persistent squeeze, a series of northwestward thrust faults are generated within the cap rock. Under the impact of the slipping layer, the faults of the section are interconnected 
in stair-step shape. At the same time, new wide-spaced anticlines characterized by the development of a cuspate anticline are constantly generated at the leading edge of the thrust, while the anticlines of the trailing edge of the thrust are gradually widened. This leads to the narrowing of the syncline and the formation of wide-spaced synclines (Yan et al. 2000). The present tectonic framework of southeastern Sichuan is not a result of movement but of upward doming and the development of anticlines, which are bound by substrate during the repeated sliding and fold contraction of the cap rock.

The southeastern Sichuan uplift is a result of the combined effects of tectonic shortening and isostatic uplift related to denudation. The study area has been influenced by tectonic compression since the Late Yanshanian. Tectonic shortening therefore becomes a major controlling factor of uplift, but the denudation of a large number of strata and the climate also play important roles in mountain building. The role of denudation in mountain building has always been the focus of geoscience research (Ollier and Pain 2000; Li et al. 2005). The paleoelevation recovery and equilibrium rebound calculation show that the denudation thickness in southeastern Sichuan is larger than $1000 \mathrm{~m}$, with the thickest denudation reaching $3000 \mathrm{~m}$. The isostatic rebound indicates that the average amplitude of crustal uplift is $354 \mathrm{~m}$, with the highest uplift of almost
$1000 \mathrm{~m}$ near Songkan town and the lowest uplift in the northwestern area of Bailu town. The surface uplift of Rongchang town and the Yongchuan district is due to the regulating effect of the detachment layer, which causes localized thickening of shallow stratum, elevated surfaces, and the occurrence of denudation. The shallow, small-scale surface uplift and the denudation exert no effect on the isostatic rebound.

\section{Uplift relationship with oil and gas}

Uplift denudation greatly influences the hydrocarbon accumulation (damage). The burial depth of the stratum becomes shallower during uplift denudation, with changes in groundwater dynamic field conditions, the formation water nature, and the development of fracture systems. Strong hydrodynamic conditions will cause morphological changes in oil and gas reservoirs, changes in the oil (gas) interface position, and even the displacement of oil and gas in entrapments. Studies have shown that the deep formation water is generally slowly alternating and stagnation filtration water, with calcium chloride water as the main type, which gradually changes upwards to magnesium chloride and finally becomes sodium bicarbonate or sodium sulfatetype water. The groundwater is moveable, which is unfavorable for preservation. The uplift process is also

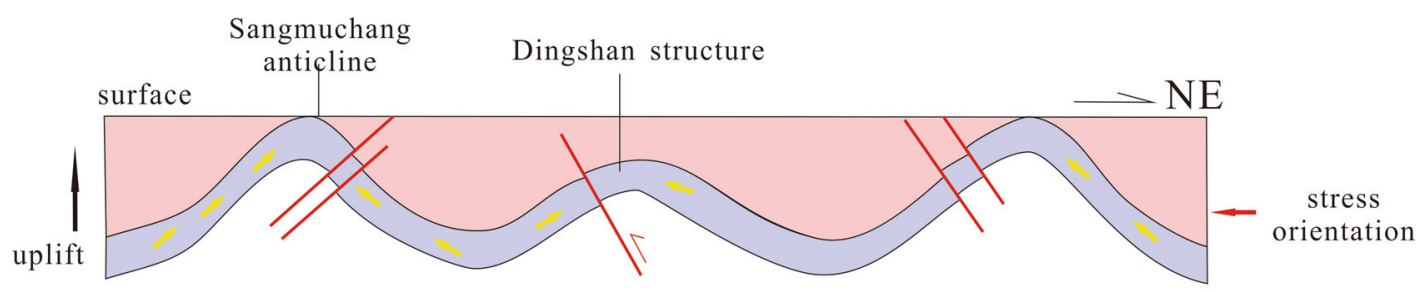

uplift, damage preservation condition and gas dissipation since Late Cretaceous

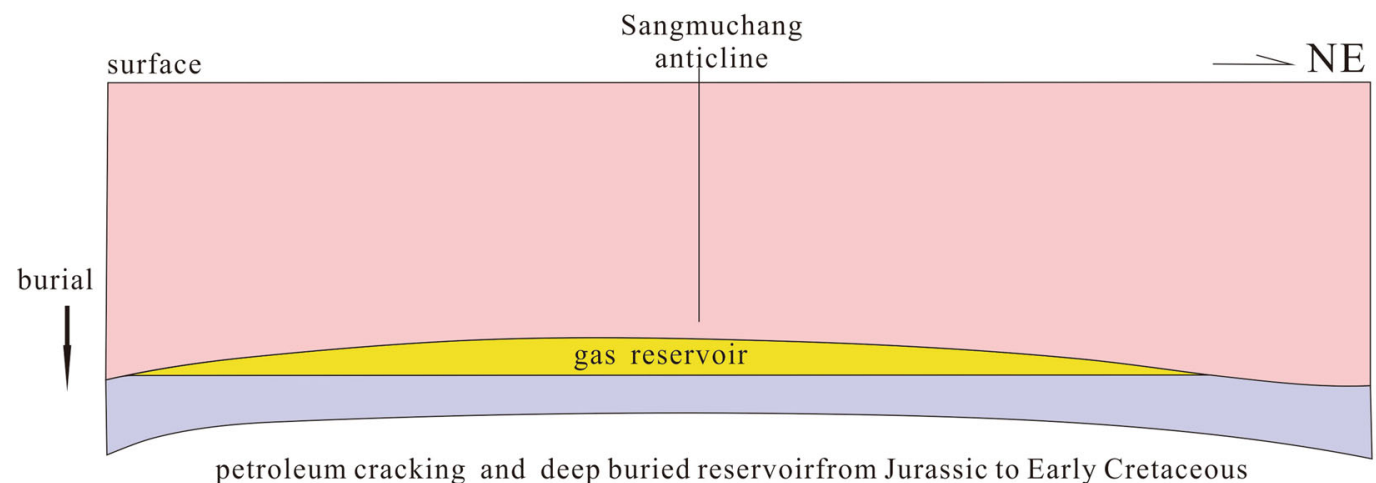

petroleum cracking and deep buried reservoirfrom Jurassic to Early Cretaceous
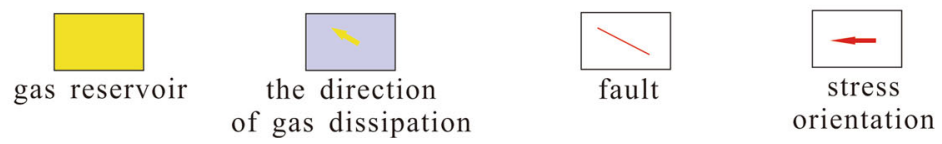

Fig. 9 Uplift impact on the hydrocarbon of Dishan block in southeastern Sichuan Basin, China 
accompanied by changes in the underground temperaturepressure field. The temperature is gradually lowered to the surface temperature to avoid the decomposition and breakage of oil and gas in the hydrocarbon source rock due to high temperature; the pressure is reduced and an extensive development of joint fissures of brittle rock is caused by the release of confining pressure, which can improve the transport conditions of shale gas and the porosity and permeability of reservoir. However, the trap preservation conditions of the oil and gas reservoir will be destroyed when the open fracture system is connected with the Earth's surface. In addition, the oil and gas will dissipate upwards when the reservoir cap is eroded or the dip angle of some areas becomes larger, which is due to the weakened closure of the overlying strata.

With the denudation of the overlying strata, the fracture system also begins development and activation. The Dingshan structure of southeastern Sichuan has been uplifted substantially since the Late Cretaceous, with the uplift rate over $2800 \mathrm{~m}$ (Fig. 8). The uplift during 90-60 Ma was denudation of approximately $20 \mathrm{~m} / \mathrm{Ma}$. Rapid uplift happened during 45-25 Ma, with a rate of uplift and denudation of approximately $110 \mathrm{~m} / \mathrm{Ma}$. Cambrian and Ordovician are exposed at structural height. The pressure coefficient of the region is only 0.95 due to uplift. As a result, the formation water in the Dengying Formation is freshwater; meanwhile, activated fractures become highspeed channels for the oil and gas escape. Pitch and hydrocarbon inclusions serve as good evidence (Fig. 9).

Acknowledgements This study was supported by the Open Research Fund Project (TPR-2015-01) of Key Laboratory of Education Department of Tectonics and Petroleum Resources, China University of Geosciences, and the National Science and Technology Major Project of China (No. 2016ZX05002-006). We would like to thank Lifu Zhou and Jiguang Tang support.

Open Access This article is distributed under the terms of the Creative Commons Attribution 4.0 International License (http:// creativecommons.org/licenses/by/4.0/), which permits unrestricted use, distribution, and reproduction in any medium, provided you give appropriate credit to the original author(s) and the source, provide a link to the Creative Commons license, and indicate if changes were made.

\section{References}

Champagnac JD, Molnar P, Anderson RS, Sue C, Delacou B (2007) Quaternary erosion-induced isostatic rebound in the western Alps. Geology 34(3):195-198

Daniel GC, Juan CL (2015) Quantifying the post-tectonic topographic evolution of closed basins. Geology 43(8):663-666

Deng B (2013) Meso-Cenozoic architecture of basin-mountain system in the Sichuan basin and its gas distribution. Chengdu University of Technology, Chengdu, pp 104-105 (in Chinese with English Abstract)

Deng DF, Mei LF, Shen CB, Liu ZQ, Tang JG, Fan YF (2014) Major factors of accumulation and destruction mechanisms of matine strata-related hydrocarbon in the Northern margin of the JiangnanXuefeng uplift. J Jilin Univ Earth Sci Edit 44(5):1466-1477

Dettman DL, Lohmann KC (2000) Oxygen isotope evidence for highaltitude snow in the Laramide Rocky Mountains of North America during the Late Cretaceous and Paleogene. Geology 28(3):339-342

Fu XD, Qing JZ, Tenger GE (2008) Evaluation on excellent marine hydrocarbon source layers in southeast area of the Sichuan Basin. Petrol Geology Exp 30(6):621-629 (in Chinese with English Abstract)

Garzione CN, Dettman DL, Quade J, Decelles PG, Butler RF (2000) High times on the Tibetan Plateau: paleoelevation of the Thakkhola graben, Nepal. Geology 28(3):329-332

Garzione CN, Dettman DL, Horton BK (2004) Carbonate oxygen isotope paleoaltimetry: Evaluating the effect of diagenesis on paleoelevation estimates for the Tibetan plateau. Palaeogeogr Palaeoclimatol Palaeoecol 212:119-140

Ge X, Shen CB, Yang Z, Mei LF, Xu SH, Liu ZQ (2013) Lowtemperature thermochronology constraints on the MesozoicCenozoic exhumation of the Huangling massif in the middle Yangtze block, central China. J Earth Sci 24(4):541-553

Green PF (1986) On the thermo-tectonic evolution of Northern England: evidence from fission track analysis. Geology 5:493-506

Gudmundsson GH (1994) An order-of-magnitude estimate of the current uplift rates in Switzerland by the Wurm Alpine deglaciation. Ecligae Geol Helvetiae 87:545-557

Huang F, Liu QY, He LJ (2012) Tectono-thermal modeling of the Sichuan Basin since the Late Himalayan period. Geophys 55(11):3742-3753 (in Chinese with English Abstract)

Jiang GL, Zhang KX, Xu YD (2015) Research progress of quantitative paleoelevation reconstruction of Tibetan Plateau. Advances in Earth Science 30(3):334-345 (in Chinese with English Abstract)

Li Y, Cao SY, Zhou RJ, Densmore AL, Ellis MA (2005) Late Cenozoic Minjiang incision rate and its constraint on the uplift of the eastern margin of the Tibetan Plateau. Acta Geol Sinica 79(1):28-37 (in Chinese with English Abstract)

Li SJ, Xiao KH, Wang XW, Zhang RQ, Wo YJ, Zhou Y, Liguo Cai (2008) Thermochronology of detrital minerals in the Silurian strata from southern China and its geological implications. Acta Geol Sinica 82(2):1068-1076 (in Chinese with English Abstract)

Li SJ, Zhou Y, Xiao KH, Wo YJ, Wang XW, Liu QY (2009) Characteristics of Silurian destroyed oil reservoir in Houtan section of Xishui area in southeastern margin of Sichuan Basin. Acta Petrolei Sinica 30(6):849-856 (in Chinese with English Abstract)

Liu XY, Yuan SH, Xu H (2009) Recent research progress in oxygenisotope paleoaltimetry. Mar Geol Quat Geol 29(2):139-147 (in Chinese with English Abstract)

Mei LF, Liu ZQ, Tang JG, Shen CB, Fan YF (2010) Mesozoic intracontinental progressive deformation in western Hunan-Hubeieastern Sichuan provinces of China: evidence from apatite fission track and balanced cross-section. Earth Sci J China Univ Geosci 35(2):161-174 (in Chinese with English Abstract)

Metiver F, Gaudenmer Y (1997) Mass transfer between eastern Tianshan and adjacent basins (Central Asia): constraints on regional tectonics and topography. Geophys J Int 128:1-17

Munt IJ, Fernandez M, Verges J, Afonso JC, Castellanos DG, Fullea J (2010) Lithospheric structure of the Gorringe Bank: insights into its origin and tectonic evolution. Tectonic 29:1-16 
Ollier C, Pain C (2000) The origin of mountain. Routledge, New York, pp 47-89

Rowley DB, Pierrehumbert RT, Currie BS (2001) A new approach to stable isotope-based paleoaltimetry: implications for paleoaltimetry and paleohypsometry of the High Himalaya since the Late Miocene. Earth Planet Sci Lett 188(1-2):253-268

Shen CB, Mei LF, Xu SH (2009) Fission track dating of Mesozoic sandstones and its tectonic significance in the Eastern Sichuan basin, China. Radiat Meas 44(9-10):945-949

Shen CB, Mei LF, Min K, Liu ZQ (2012) Multi-chronometric dating of the Huarong granitoids from the Middle Yangtze Craton: implications for the tectonic evolution of eastern China. J Asian Earth Sci 52:73-87

Stern TA, Baxter AK, Barrett PJ (2005) Isostatic rebound due to glacial erosion within the Transantarctic Mountains. Geology 33:221-224

Talbot MR (1990) A review of the paleohydrological interpretation of carbon and oxygen isotopic ratios in primary lacustrine carbonates. Chem Geol 80:261-279

Wang Y, Xu HZ (1996) The variations of lithospheric flexural strength and isostatic compensation mechanisms beneath the continent of China and vicinity. Chin J Geophys 39(Supp):105-112 (in Chinese with English Abstract)

Wang XW, Wo YJ, Zhou Y, Zhang RQ, Li SJ, Yuan YS (2011) Primary discussion on relationship between hydrocarbon preservation and tectonic movement. Petrol Geol Exp 33(1):34-43 (in Chinese with English Abstract)

Wang P, Liu SF, Wang K, Gao TJ (2012) Structural deformation and origin of the arcuate fold- thrust belt in western Hubei Province. Chin J Geol 47(1):22-36 (in Chinese with English Abstract)
Willett SD, Brandon MT (2002) On steady states in mountain belts. Geology 30:175-178

Wu ZH, Zhao X, Ye PS, Wu ZH, Hu DG, Zhou CJ (2007) PaleoElevation of the Tibetan Plateau inferred from carbon and oxygen isotopes of lacustrine deposits. Acta Geol Sinica 81(9):1277-1289 (in Chinese with English Abstract)

Yan DP, Wang XW, Liu YY (2000) Analysis of fold style and its formation mechanism in the area of boundary among Sichuan, Hubei and Hunan. Geoscience 14(1):37-43 (in Chinese with English Abstract)

Yang HM, Wang CS (2007) Paleohypsometry: new application of hydrogen isotope and oxygen isotope. Advances in earth science 22(9):960-968 (in Chinese with English Abstract)

Ye JR, Shao R, Wang LJ (2000) Research into fluid pressure field in Damintun depression, Liaohe basin. Earth Sci J China Univ Geosci 25(2):127-132

Yuan WM, Yang ZQ, Zhang ZC (2011) The uplifting and denudation of main Huangshan Mountains, Anhui province, China. Sci China Earth Sci 54(8):1168-1176

Zhai CB (2013) Reservoir forming condition and exploration prospect of shale-gas in Qijiang- Renhuai area of southeast Sichuan Basin. China University of Geosciences, Beijing, pp 17-22 (in Chinese)

Zhao WJ, Yuan WM, Liu HT, Song G (2013) Apatite fission track analysis on tectonic activoties and paleotopography in Southern Altai region, Xinjiang, China. Atomic Energy Sci Technol 47(8):1458-1468 